\title{
First Report of Blood Fluke Pathogens with Potential Risk for Emerging Yellowtail Kingfish (Seriola lalandi) Aquaculture on the Chilean Coast, with Descriptions of Two New Species of Paradeontacylix (Aporocotylidae)
}

\author{
Fabiola A. Sepúlveda ${ }^{1}$, Luis A. Nacari ${ }^{2}$ and Maria Teresa González ${ }^{1, *}$ \\ 1 Instituto de Ciencias Naturales Alexander von Humboldt, \\ Facultad de Ciencias del Mar y Recursos Biológicos, Universidad de Antofagasta, Angamos 601, \\ Antofagasta 1240000, Chile; fabiolasepu@gmail.com \\ 2 Programa Doctorado en Ciencias Aplicadas, Facultad de Ciencias del Mar y Recursos Biológicos, \\ Universidad de Antofagasta, Angamos 601, Antofagasta 1240000, Chile; LUIS.NACARI.ENCISO@ua.cl \\ * Correspondence: teresa.gonzalez@uantof.cl
}

Citation: Sepúlveda, F.A.; Nacari, L.A.; González, M.T. First Report of Blood Fluke Pathogens with Potential Risk for Emerging Yellowtail Kingfish (Seriola lalandi) Aquaculture on the Chilean Coast, with Descriptions of Two New Species of Paradeontacylix (Aporocotylidae). Pathogens 2021, 10, 849. https://doi.org/10.3390/ pathogens 10070849

Academic Editor: Louise Von Gersdorff Jørgensen

Received: 20 April 2021

Accepted: 11 May 2021

Published: 6 July 2021

Publisher's Note: MDPI stays neutral with regard to jurisdictional claims in published maps and institutional affiliations.

Copyright: (c) 2021 by the authors. Licensee MDPI, Basel, Switzerland. This article is an open access article distributed under the terms and conditions of the Creative Commons Attribution (CC BY) license (https:// creativecommons.org/licenses/by/ $4.0 /)$.

\begin{abstract}
Blood flukes are digeneans that infect wild and farmed fish that can cause a severe and potentially lethal disease in farmed fish. These parasites are undetectable in the larval stage based on macroscopic observations in the definitive host with the infection becoming evident when eggs accumulate in the branchial vessels. There are nine known species of the genus Paradeontacylix and seven exclusively parasitize Seriola spp. from several geographical areas. Seriola lalandi aquaculture farms are emerging at various localities in northern Chile. Here, we report, for the first time, two blood fluke species parasitizing S. lalandi in the Southeastern Pacific (Chile). In the laboratory, the gills and heart of fish were removed. The retained blood flukes were separated according to the infection site, fixed in $70 \%$ or $95 \%$ ethanol for taxonomic and molecular analysis, respectively. Morphometrical differences among the fluke species were evaluated with a principal component analysis (PCA) using proportional body measurements. Phylogenetic trees were constructed based on 28S rDNA, cox1 mDNA using Bayesian inference (BI), and maximum likelihood (ML). Based on morphology, morphometry, and molecular analyses, two new species are proposed: P. humboldti n. sp. from the gills and P. olivai n. sp. from the heart of $S$. lalandi. Both were clearly distinguished from other species of Paradeontacylix by a combination of morphologic features (posterior tegumental spines, testes arrangement, body size). The genetic distance (based on cox 1 ) among species was $>10 \%$. $P$. humboldti n. sp. and P. olivai n. sp. are sister species (with a common ancestor) independent of $P$. godfreyi from $S$. lalandi in Australia. The newly identified parasites may pose a risk to farmed $S$. lalandi as aporocotylids have been the cause of diseases in farmed fish from other geographical areas. In addition, some cages of $S$. lalandi are currently maintained in an open circulating system, which could favor the transmission of these parasites (if involved hosts are present in the environment).
\end{abstract}

Keywords: aporocotylids; host specificity; molecular analyses; morphology; new species

\section{Introduction}

Blood flukes are digeneans that infect the circulatory systems of wild and farmed fish [1-3] and can cause a severe disease in farmed Seriola spp. [4-7]. The disease occurs because the eggs accumulate in the gill filaments, leading to gill hyperplasia, egg encapsulation in the gills and ventricle, and papillae formation due to endothelial proliferation in the afferent branchial arteries [8]. In addition, hatching miracidia may cause multiple lesions and microhemorrhages, which in turn can trigger an inflammatory response and result in anemia [5]. This is especially the case when a massive hatch occurs, as has been reported for Sanguinicola inermis in Cyprinus carpio [9] and Cardicola sp. in Sparus aurata [10]. This pathology could be harmful in the aquaculture industry due this infection becoming 
evident when eggs accumulate in the branchial vessels and the fish become moribund [11]. Dead fish are characterized by an opened mouth and opercula, showing typical sign of suffocation [12]. The disease has been reported to be responsible for important losses regarding Seriola dumerili aquaculture, reaching $50-80 \%$ of the mortalities among fish in the $0+$ and $1+$ classes $[5,12,13]$.

Blood flukes are restricted to a limited range of closely related definitive hosts. To date, nine aporocotylid species of the genus Paradeontacylix have been reported to almost exclusively parasitize Seriola spp. (Carangidae) in at least four geographical areas: the northwest Atlantic, northwest Pacific, southwest Pacific, and Mediterranean [4,14-17]. Seven of the nine species of Paradeontacylix infest Seriola spp.: P. sanguinicoloides parasitizes wild Seriola dorsalis (as Seriola lalandi) in Florida (northwest Atlantic [14]) but corresponding S. dorsalis [18], P. grandispinus, and P. kampachi parasitize farmed S. dumerili in Japan (northwest Pacific [4]); P. godfreyi parasitizes wild S. lalandi in Australia (Indian Pacific Ocean [17]); P. balearicus and P. ibericus parasitize wild S. dumerili on the Balearic Islands and Iberian Peninsula, respectively (Mediterranean); and P. buri parasitizes farmed S. quinqueradiata in Japan (northwest Pacific [16]). By contrast, P. megalaspium and P. odhneri have been reported to parasitize fish species other than the genus Seriola, e.g., Megalaspis cordyla (Carangidae) and Takifugu porphyreus (Tetraodontidae), respectively [19,20]. However, due to its atypical morphologic traits, it has been suggested that P. odhneri does not belong to Paradeontacylix $[15,16]$.

For the emerging aquaculture industry to become sustainable and successful, it is essential to identify risk factors [21]. For this, the detection and correct identification of pathogenic parasites is an important first step [3,22]. Seriola spp. are successfully cultivated around the world, but not without diseases [21,23,24]. Although mass mortalities caused by Paradeontacylix spp. have been reported among farmed S. dumerili [4,12] and S. quinqueradiata [23] in Japan, and among farmed S. dumerili $[5,13]$ in the Mediterranean, there are no records of this disease among farmed S. lalandi [17]. On the southeast Pacific coast, $S$. lalandi is one of the most important fish candidates for aquaculture diversification in Chile, and aquaculture activities have already begun at various localities in northern Chile [25-27]. The experimental cultures of yellowtail kingfish began in facilities of the Universidad de Antofagasta in the year 2000. Three other experimental cultures started in the last ten years (Univ. Tarapaca, Univ. Arturo Prat, and Chile Foundation UCN). The only company that cultivates fish commercially began its productive operations in 2008 . This company maintains a mixed culture system of wild and farmed native specimens with tanks conditioned with a recirculating aquatic system. All the cultures in the experimental phase capture fish from the environment to maintain and to increase the number of brood fish.

Moderate-to-heavy infections involving the parasites Zeuxapta seriolae [28], Benedenia humboldti [27,29,30], and Caligus lalandei [27] have been reported in wild and farmed Seriola lalandi from the Chilean coast. Additionally, Neobenedenia sp. has only been reported in farmed S. lalandi [31] and there are not previous reports of blood flukes in wild or captive S. lalandi. However, recently, one dead S. lalandi from the experimental facility of Univ. Antofagasta was necropsied, and blood flukes were recovered from the heart and branchial arteries and numerous eggs were found in the branchial filaments. The parasites were identified as species of Paradeontacylix, indicating that the fish death was due to the parasites (pers. obs.). Consequently, the objective of this study was to report, for the first time, blood flukes infecting wild and farmed Seriola lalandi (experimental culture) from the Chilean coast (southeastern Pacific). Additionally, based on the differences in morphologic, morphometric, and molecular characteristics of the blood flukes obtained in this study compared to known species, two new species of Paradeontacylix are proposed and described here (Paradeontacylix humboldti n. sp. and Paradeontacylix olivai n. sp.).

\section{Results}

All specimens collected in this study were morphologically identified as Paradeontacylix spp. From here on, those will be referred to as Paradeontacylix olivai n. sp. and 
Paradeontacylix humboldti $\mathrm{n}$. sp. The specimens P. olivai $\mathrm{n}$. sp. were obtained from the heart and they were bigger than specimens $P$. humboldti $\mathrm{n}$. sp. obtained from the blood vessels (Figure 1). P. olivai n. sp. was present in wild and farmed S. lalandi with an intensity of infection varying between 1 and 5 worms per fish heart (mean intensity $=2.3$; prevalence $=20 \%$ ). All of them were adults with eggs. About 39 eggs of P. olivai were recovered from gill filaments of farmed fish (Figure S1). P. humboldti was present only in farmed fish with an intensity of infection of 20 worms recovered from an afferent branchial artery.


Figure 1. Light microscopy photographs of Paradeontacylix sp. from Seriola lalandi on the Chilean coast. (A) Ventral view of complete body of Paradeontacylix humboldti n. sp. and (B) details of posterior region. (C) Ventral view of complete body of Paradeontacylix olivai n. sp. and (D) details of posterior region. Abbreviations: lps, large posterior spines; ms, marginal spines; o, ovary. Scale bars: (A,C), $250 \mu \mathrm{m}$; (B,D), $50 \mu \mathrm{m}$.

\subsection{Morphometric Analysis}

PCA analysis showed that PC1, involving body width, male genital pore-posterior end distance, ovary length, ovary width, oviducal seminal receptacle length, oviducal seminal receptacle width, oötype length, and oötype width, explained $40 \%$ of the total variance. PC2, involving number of testes/BL and female genital pore-posterior end distance/BL, explained $18 \%$ of the total variance. Together, PC1 and PC2 explained $58 \%$ of the variance. P. kampachi and P. ibericus were in one group, and there was some overlap between $P$. sanguinicoloides and P. godfreyi. However, P. grandispinus, P. balearicus, and the two new species identified in this study were clearly different from each other (Figure 2).

\subsection{Molecular Analysis}

The unique sequences obtained in this study were coded with the following access numbers: MW599287-MW599288 (28S LSU rDNA) and MW598468-MW598470 (cox1 mDNA) (Table 1). Three sequences of P. humboldti $\mathrm{n}$. sp. and five sequences of P. olivai $\mathrm{n}$. sp. were obtained for each gene: 28S LSU rDNA (902 bp in length) and the cox1 mDNA (743 bp in length), respectively (Table 1). Regarding the $28 \mathrm{~S}$ LSU rDNA, there was no intraspecific polymorphic sites for either species but there were 11 polymorphic sites between the new candidate species (P. humboldti n. sp. and P. olivai n. sp.). Regarding the cox1 gene, there were no intraspecific polymorphic sites among cox 1 sequences of $P$. humboldti $\mathrm{n}$. sp. while only one intraspecific polymorphic site was detected for P. olivai n. sp. and 67 polymorphic sites were detected between the new candidate species. 


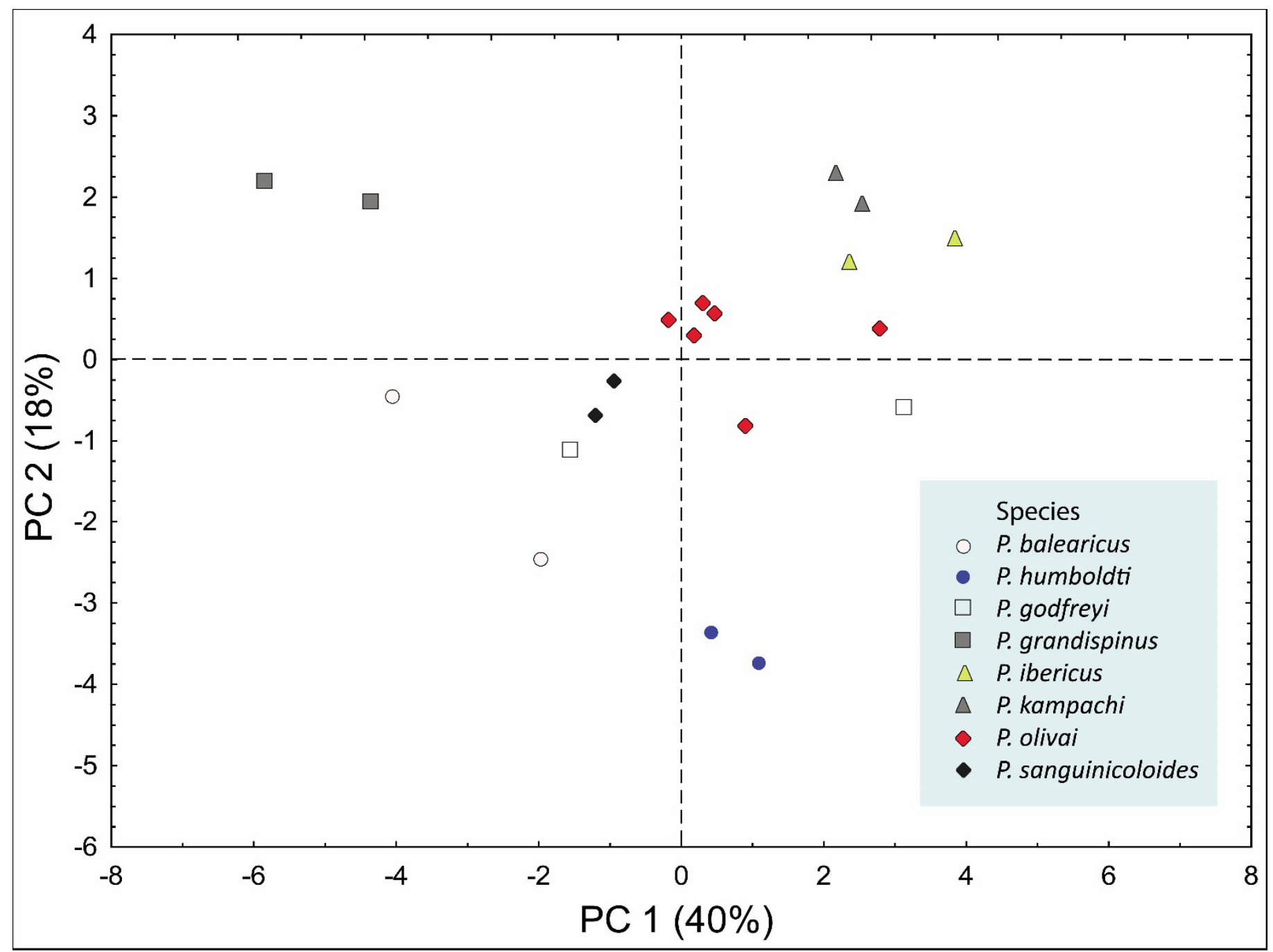

Figure 2. Results of multivariate analyses of proportional measurements of Paradeontacylix spp. Each symbol in the graph is defined in the box on the lower right.

Table 1. List of blood fluke species, host species, geographic reports, and GenBank accession numbers (nuclear and mitochondrial genes) used in this study. N, number of specimens belonging to different Paradeontacylix species used for morphometrical/molecular analyses.

\begin{tabular}{ccccccc}
\hline \multirow{2}{*}{ Species } & \multirow{N}{*}{} & \multirow{2}{*}{ Host } & Country & \multicolumn{2}{c}{ Access Number } & Author(s) \\
\cline { 4 - 5 } & & & $\mathbf{2 8 S}$ & cox1 & \\
\hline P. balearicus & $2 / 1$ & Seriola dumerili & Spain & AM489594 & AM489604 & Repullés-Albelda et al., 2008 \\
P. buri & $-/ 1$ & S. quinqueradiata & Japan & AB904154 & - & Ogawa et al., 2015 \\
P. godfreyi & $2 / 1$ & S. lalandi & Australia & AM489597 & AM489607 & Repullés-Albelda et al., 2008 \\
P. grandispinus & $2 / 1$ & S. dumerili & Japan & AM489596 & AM489606 & Repullés-Albelda et al., 2008 \\
P. humboldti & $2 / 3$ & S. lalandi & Chile & MW599287 & MW598468 & This study \\
P. ibericus & $2 / 1$ & S. dumerili & Spain & AM489593 & AM489603 & Repullés-Albelda et al., 2008 \\
P. kampachi & $2 / 1$ & S. dumerili & Japan & AM489595 & AM489605 & Repullés-Albelda et al., 2008 \\
P. olivai & $8 / 5$ & S. lalandi & Chile & MW599288 & MW598468-70 & This study \\
P. sanguinicoloides & $2 /-$ & S. dorsalis & Florida & - & - & McIntosh, 1934 \\
Cardicola forsteri & - & Thunnus thynnus & Spain & EF653388 & KP988302 & Aiken et al., 2007/Palacios-Abella et al., 2015 \\
Cardicola opisthorchis & - & Thunnus thynnus & Spain & KP217052 & KP988305 & Unpublished/Palacios-Abella et al., 2015 \\
Psettarium nolani & - & Arothron hispidus & Australia & MG709043 & - & Yong et al., 2018 \\
Psettarium sinensis & - & Fugu rubripes & China & EU368853 & - & Unpublished \\
Plethorchis acanthus & - & Mugil cephalus & Australia & AY222178 & - & Olson et al., 2003 \\
\hline
\end{tabular}


The final alignment of all datasets (including the Paradeontacylix spp. sequences from GenBank) resulted in $910 \mathrm{bp}$ for $28 \mathrm{~S}$ LSU rDNA and $416 \mathrm{bp}$ for cox $1 \mathrm{mDNA}$. Phylogenetic reconstructions based on the total molecular evidence $(910 \mathrm{bp}+416 \mathrm{bp}=1326 \mathrm{bp})$ resulted in the same general topology for both inference methods (ML and BI) (Figure 3). The species of Paradeontacylix were clustered into a single monophyletic clade, which was strongly supported by a high posterior probability in the BI analysis $(\mathrm{pp}=1)$ and by the bootstrap support value in the ML analysis $(b M L=99)$ (Figure 3). In each phylogenetic tree there were three subclades with moderate-to-strong statistical support: one involved P. humboldti n. sp. and P. olivai n. sp., the second clade (which is a sister clade of the new candidate species) involved P. balearicus and P. grandispinus, and the third clade involved P. ibericus and P. kampachi (Figure 3). P. godfreyi appeared as a basal species within the genus Paradeontacylix.

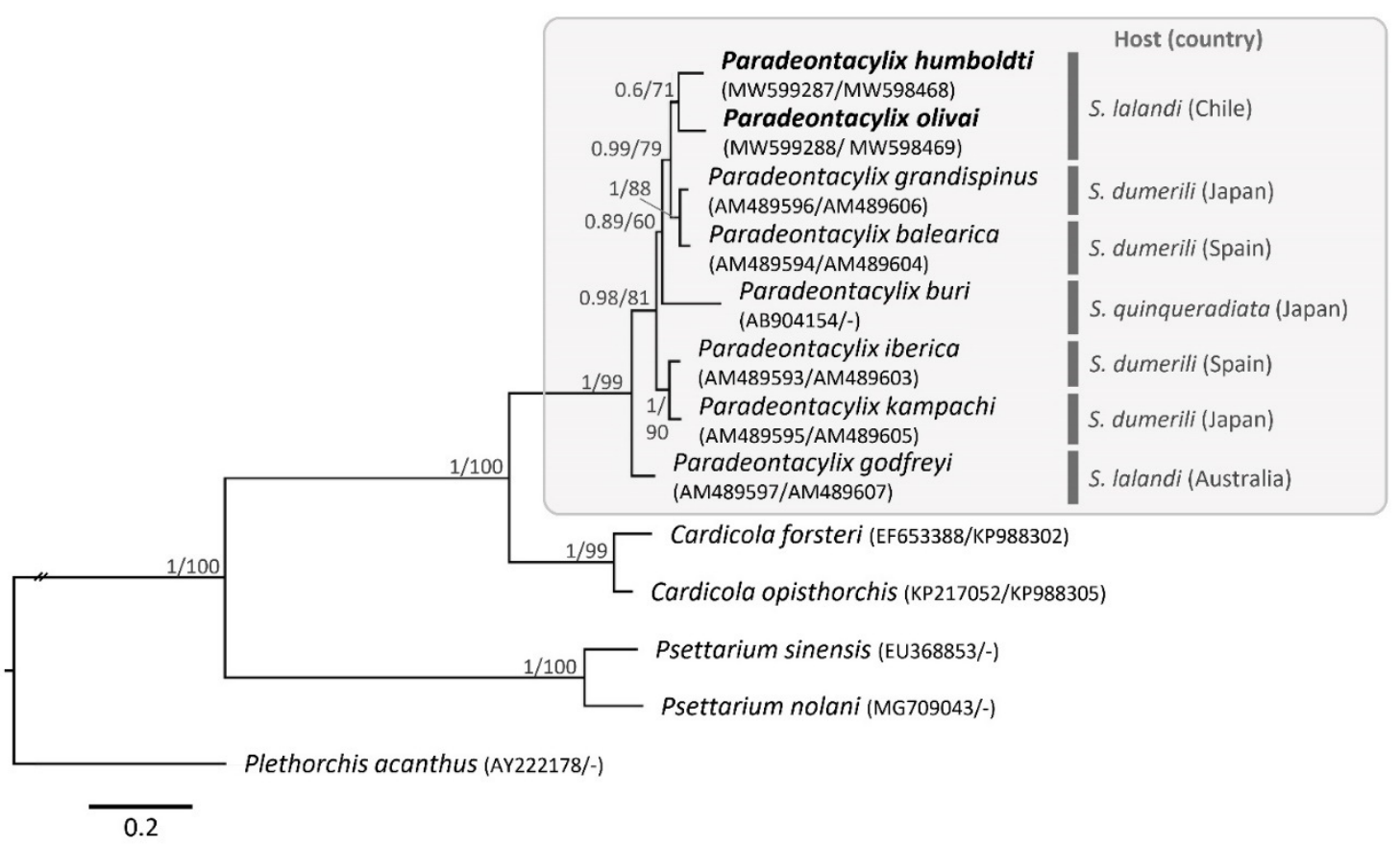

Figure 3. Phylogenetic tree based on partial 28S LSU rDNA and cox 1 mDNA sequences of Paradeontacylix spp. Numbers at the nodes show posterior probability based on the Bayesian inference analysis/bootstrap support values based on 1000 replicates in the maximum likelihood analysis.

Based on cox 1 mDNA, P. humboldti n. sp. and P. olivai n. sp. had genetic distances $>10 \%$ between them and between them and the other species of Paradeontacylix. The pairwise sequence divergences for each of the two molecular markers are shown in Table 2.

Table 2. Genetic distance between Paradeontacylix spp based on 28S LSU rDNA and cox1 mDNA, respectively. Lower half shows the percentage differences between the paired comparisons using $28 \mathrm{~S}$ LSU rDNA (based on $910 \mathrm{bp}$ ) and upper half shows the percentage differences between the paired comparisons using cox1 (based on $416 \mathrm{bp}$ ).

\begin{tabular}{cccccccccc}
\hline & Species & $\mathbf{1}$ & $\mathbf{2}$ & $\mathbf{3}$ & $\mathbf{4}$ & $\mathbf{5}$ & $\mathbf{6}$ & $\mathbf{7}$ & $\mathbf{8}$ \\
\hline 1 & P. humboldti & & 10.26 & 10.50 & - & 11.69 & 16.47 & 11.93 & 13.84 \\
2 & P. olivai & 1.25 & & 10.74 & - & 12.17 & 15.51 & 11.22 & 11.93 \\
3 & P. grandispinus & 1.02 & 1.02 & & - & 11.69 & 13.84 & 6.20 & 11.46 \\
4 & P. buri & 2.39 & 2.39 & 2.05 & & - & - & - & - \\
5 & P. ibericus & 1.59 & 1.59 & 1.25 & 1.94 & & 15.99 & 11.46 & 6.921 \\
6 & P. godfreyi & 1.48 & 1.48 & 1.14 & 2.05 & 0.79 & & 13.6 & 15.04 \\
7 & P. balearicus & 1.02 & 1.02 & 0.23 & 2.05 & 1.25 & 1.14 & & 11.46 \\
8 & P. kampachi & 1.48 & 1.48 & 1.14 & 1.82 & 0.23 & 0.68 & 1.14 & \\
\hline
\end{tabular}




\subsection{Morphologic Descriptions}

\subsubsection{Paradeontacylix humboldti $\mathrm{n}$. sp.}

Description

Host: Seriola lalandi Valenciennes, 1833.

Locality: San Jorge Bay ( $\left.23^{\circ} 35^{\prime} \mathrm{S}, 70^{\circ} 25^{\prime} \mathrm{W}\right)$, off Antofagasta, northern Chile.

Location in host: Afferent branchial artery.

Representative sequences: GenBank accession numbers, partial 28S LSU rDNA MW599287; cox1 mDNA MW598468.

Etymology: The species is named in honor of German naturalist Alexander von Humboldt.

Specimens: Holotype and one paratype have been deposited in the MNHNCL, encoded as: PLAT-15021 and PLAT-15022, respectively.

Based on two whole-mounted gravid adult specimens. Body measurements are given in Table 3. Body smooth, elongated, dorsoventrally flattened, lancet-shaped (Figure 4A). Longer than wide by $12-13(12.5, \mathrm{n}=2)$ times. Marginal tegumental spines ventrolateral, 286-436 (361, n = 4) rows on either side of body; same size throughout body, averaging 4 long by 1 wide (maximum width at spine base), 4-9 per row, decreasing in number toward both extremities to about 4 at anterior and posterior ends. Posteriorly, 9 large tegumental spines, conspicuous, claw-like distally, arranged in 4 longitudinal rows each comprising 2-3 spines (Figure $4 \mathrm{C}$ ). Additionally, medium-sized posterior tegumental spines, arranged on either side of large spines in 3 rows (Figure $4 \mathrm{C}$ ).

Nerve commissure 110-131 (121, $\mathrm{n}=2)$ from anterior end. Mouth opening ventrosubterminally, $28(\mathrm{n}=2)$ from anterior end. Esophagus sinuous, gradually widening toward its end, surrounded by conspicuous gland cells positioned at 342-451 $(396, n=2)$ from oesophagus anterior end. Short anterior and elongate posterior intestinal caeca forming H-shaped; anterior caeca 47-48 (48, $\mathrm{n}=4)$ long; posterior caeca 688-878 $(783, \mathrm{n}=4)$ long, terminating blindly among testicular field, anterior to ovary (Figure $4 \mathrm{~A}$ ).

Testes arranged irregularly between posterior caeca, round or ellipsoidal. Testicular zone occupying $33 \%(n=2)$ of body length (Figure $4 A$ ). Vas deferens starting from posterior testes, passing ovary dorsally, following curved path to form seminal vesicle filling entire cirrus sac (Figure 4B). Seminal vesicle enclosed in cirrus sac (Figure 4B). Cirrus pouch thin-walled (Figure 4B). Male genital pore dorsal, 12-24 (18, $\mathrm{n}=2$ ) from sinistral body margin, 257-349 $(303, n=2)$ from posterior end of body (Figure 4B).

Ovary oval-shaped, posterior to testes, ventral to vas deferens, corresponding to $25-26 \%(25.5 \%, n=2)$ of body length (Figure $4 \mathrm{~B})$. Oviduct originating at posterior end part of ovary. Expanding in the middle of oviduct is form oviducal seminal receptacle (Figure 4B). Oviducal seminal receptacle narrowing progressively and joining common vitelline duct before forming oötype (Figure 4B). Oötype slightly on its dextral side, 202-236 $(219, \mathrm{n}=2)$ from posterior end of body, surrounded by Mehlis' gland (Figure 4B). Vitelline duct passing posteriorly, sinistral to oviduct. Uterus occupying zone from level of posterior end of ovary to level slightly behind oötype, sinistral to common vitelline duct, after ascending through several coils (filling space immediately posterior to ovary) and then descending to female genital pore (Figure 4B). Female genital pore dorsal, opening on sinistral side, antero-sinistral to male genital pore, 28-31 $(30, n=2)$ from sinistral body margin, 145-208 $(177, \mathrm{n}=2)$ from male genital pore, 409-548 $(478, \mathrm{n}=2)$ from posterior end of body. Eggs ellipsoidal (Figure 4B). Excretory vesicle and pore not observed. Vitellarium extending from level of nerve commissure to level of posterior end of ovary (Figure 4A).

\section{Remarks}

The P. humboldti n. sp. displays all the diagnostic characteristics of the genus $P a$ radeontacylix McIntosh, 1934. Here, we have initially classified it as a species of the genus Paradeontacylix according to testes distribution as irregular (random, without a pattern) and regular (in two well-defined rows). Based on this criterion, the first group includes $P$. grandispinus, P. balearicus, P. sanguinicoloides, and P. godfreyi with irregular testes distribution, while a second group includes: P. kampachi, P. buri, P. ibericus, and P. megalaspium, which 
present regular distribution. The distribution of testes in the new species P. humboldti n. sp. is irregular. Additionally, it differs significantly in the number of testes, intestine shape, and ovary shape from P. grandispinus (63-69 vs. 19-32 testes; H-shaped vs. X-shaped intestine; oval-shaped vs. heart-shaped ovary, respectively) and P. balearicus (63-69 vs. 20-26 testes; H-shaped vs. X-shaped intestine; oval-shaped vs. shield-shaped ovary, respectively). It also differs from $P$. sanguinicoloides in the shape of the large posterior tegumental spines (claw vs. rose thorn, respectively), ovary shape (oval-shaped vs. heart-shaped, respectively) and position of female genital pore (antero-sinistral vs. antero-mesal of male genital pore, respectively). P. humboldti n. sp. differs from P. godfreyi in the ovary shape (oval-shaped vs. heart-shaped) and testes position in the body (middle and posterior vs. posterior third). It is also approximately half of the maximum body widths of P. sanguinicoloides (155-179 vs. 330, respectively) and P. godfreyi (155-179 vs. 357-566, respectively). P. humboldti n. sp. is half the body length of $P$. godfreyi (1858-2352 vs. 3739-4215, respectively). Additionally, the position of the female genital pore, which opens without crossing vas deferens, is only shared with S. godfreyi.

Table 3. Body measurements of Paradeontacylix humboldti n sp. and Paradeontacylix olivai n. sp infecting Seriola lalandi from Chile.

\begin{tabular}{|c|c|c|}
\hline Body Measurement & Paradeontacylix humboldti n. sp. & Paradeontacylix olivai n. sp. \\
\hline Body length & $1858-2353(2105, \mathrm{n}=2)$ & $3567-5214(4099, \mathrm{n}=8)$ \\
\hline Body maximum width & $155-179(167, \mathrm{n}=2)$ & $204-369(324, \mathrm{n}=8)$ \\
\hline Marginal tegumental spine rows & $286-436(361, \mathrm{n}=4)$ & $478-650(563, n=6)$ \\
\hline Marginal tegumental spine length & 4 & $5-8(6, n=7)$ \\
\hline Marginal tegumental spine width & 1 & $1-2(1.6, n=7)$ \\
\hline Marginal tegumental spine per row & [4-9] & [3-14] \\
\hline No. of large posterior tegumental spines [No. spines $\times$ No. rows] & $([(2-3) \times 4]-[(2-3) \times 4])$ & {$[(3-5) \times 4]$} \\
\hline Large posterior tegumental spines length & $15-22(19, \mathrm{n}=18)$ & $15-39(24, \mathrm{n}=30)$ \\
\hline Large posterior tegumental spines width (maximum wide at spine base) & $3-5(4, n=18)$ & $4-7(5, \mathrm{n}=30)$ \\
\hline No. of medium posterior tegumental spines [No. spines $\times$ No. rows] & {$[3 \times 3]$} & {$[(3-4) \times 3]$} \\
\hline Medium posterior tegumental spines length & $7-13(9, \mathrm{n}=12)$ & $6-17(11, n=16)$ \\
\hline Medium posterior tegumental spines width & $1-2(2, \mathrm{n}=12)$ & $2-4(3, \mathrm{n}=18)$ \\
\hline Mouth opening from anterior end & $28(\mathrm{n}=2)$ & $8-22(16, n=7)$ \\
\hline Oesophagus length & $533-660(597, \mathrm{n}=2)$ & $496-1268(1040, n=7)$ \\
\hline Oesophagus (percentage of body length) & $28-29 \%(n=2)$ & $14-30 \%(25 \%, n=7)$ \\
\hline Oesophagus's glands cell from anterior end length & $342-451(396, \mathrm{n}=2)$ & $706-962(814, \mathrm{n}=6)$ \\
\hline Intestine anterior caeca length & $47-48(48, \mathrm{n}=4)$ & $60-126(103, \mathrm{n}=14)$ \\
\hline Intestine posterior caeca length & $688-878(783, \mathrm{n}=4)$ & $1622-2436(1848, \mathrm{n}=12)$ \\
\hline Testes number & $63-69(66, n=2)$ & $41-45(43, \mathrm{n}=7)$ \\
\hline Testes length (average) & $26-28(27, \mathrm{n}=2)$ & $47-72(53, \mathrm{n}=5)$ \\
\hline Testes width (average) & $20-22(21, \mathrm{n}=2)$ & $74-108(92, \mathrm{n}=5)$ \\
\hline Testicular field length & $613-766(689, \mathrm{n}=2)$ & $1165-1862(1491, \mathrm{n}=8)$ \\
\hline Testicular field (percentage of body length) & $33 \%(n=2)$ & $33-40 \%(36 \%, n=8)$ \\
\hline Vesicula seminalis length & $86-112(99, \mathrm{n}=2)$ & $187-268(234, \mathrm{n}=6)$ \\
\hline Vesicula seminalis wide & $11-16(13.5, \mathrm{n}=2)$ & $23-43(31, n=6)$ \\
\hline Cirrus sac length & $86-114(100, \mathrm{n}=2)$ & $184-283(226, \mathrm{n}=7)$ \\
\hline Cirrus sac width & $30-49(39.6, \mathrm{n}=2)$ & $60-94(76, \mathrm{n}=7)$ \\
\hline Cirrus length & - & $47-65(55, \mathrm{n}=3)$ \\
\hline Cirrus width & $24-34(29, \mathrm{n}=2)$ & $37-60(45.27, \mathrm{n}=3)$ \\
\hline Ovary length & $99-124(111, \mathrm{n}=2)$ & $174-342(244, \mathrm{n}=8)$ \\
\hline Ovary width & $99-124(111, \mathrm{n}=2)$ & $115-306(211, \mathrm{n}=8)$ \\
\hline Ovary from its posterior end to posterior end of body & $481-597(539, \mathrm{n}=2)$ & $778-1100(911, \mathrm{n}=8)$ \\
\hline Ovary from its posterior end of body end (percentage of body length) & $25-26 \%(25.5 \%, \mathrm{n}=2)$ & $21-23 \%(22 \%, \mathrm{n}=8)$ \\
\hline Oviduct length & $163-174(169, \mathrm{n}=2)$ & $183-336(262, \mathrm{n}=7)$ \\
\hline Oviducal seminal receptacle length & $81-93(87, \mathrm{n}=2)$ & $174-254(214, \mathrm{n}=7)$ \\
\hline Oviducal seminal receptacle width & $19-21(20, \mathrm{n}=2)$ & $34-54(44, \mathrm{n}=7)$ \\
\hline Oötype length & $20-22(21, \mathrm{n}=2)$ & $42-66(57, \mathrm{n}=6)$ \\
\hline Oötype width & $14-18(16, \mathrm{n}=2)$ & $33-75(50, \mathrm{n}=6)$ \\
\hline Oötype from posterior end of body & $202-236(219, \mathrm{n}=2)$ & $330-443(361, \mathrm{n}=6)$ \\
\hline Female genital pore from sinistral body margin & $28-31(30, n=2)$ & $102-174(143, \mathrm{n}=5)$ \\
\hline Distance between male and female genital pores & $145-208(177, \mathrm{n}=2)$ & $167-204(190, \mathrm{n}=5)$ \\
\hline Female genital pore from posterior end of body & $409-548(478, \mathrm{n}=2)$ & $616-753(664, \mathrm{n}=5)$ \\
\hline Eggs length & $18-21(20, \mathrm{n}=20)$ & $26-37(31, \mathrm{n}=15)$ \\
\hline Eggs width & $13-16(15, \mathrm{n}=20)$ & $28-28(24, \mathrm{n}=15)$ \\
\hline
\end{tabular}




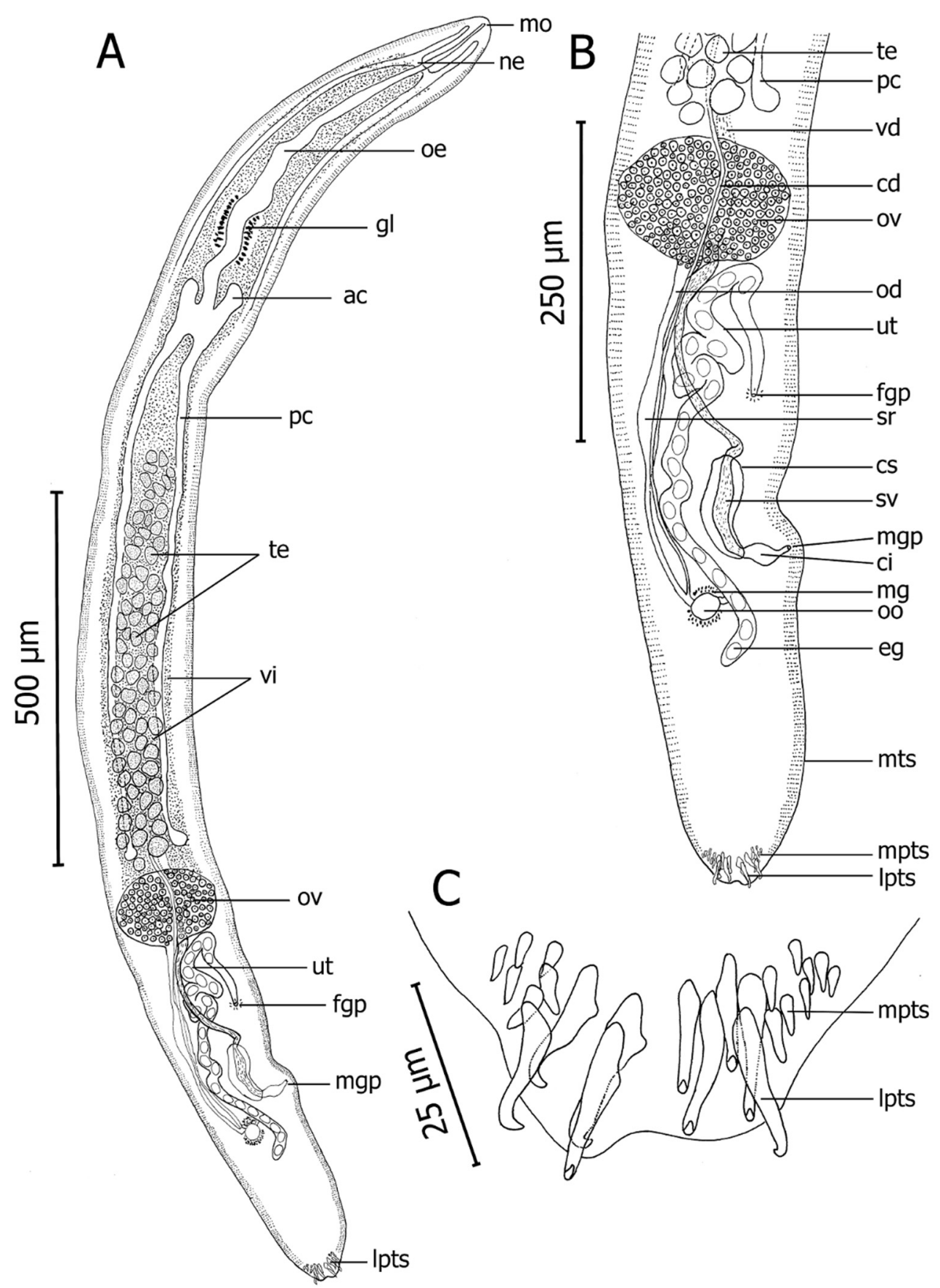

Figure 4. Holotype of Paradeontacylix humboldti n. sp. from afferent branchial artery of Seriola lalandi. (A) Ventral view of whole worm. (B) Ventral view of posterior part of body showing one part of testicular field and post-ovarian region. (C) Posterior tegumental spines showing large claw-like posterior tegumental spines. Abbreviations: ac, anterior caeca; cd, common vitelline duct; ci, cirrus; cs, cirrus sac; eg, eggs; fgp, female genital pore; gl, gland cells; lpts, large posterior tegumental spines; mg, Mehlis' gland; mgp, male genital pore; mo, mouth; mpts, medium posterior tegumental spines; mts, marginal tegumental spines; ne, nerve commissure; od, oviduct; oe, oesophagus; oo, oötype; ov, ovary; pc, posterior caeca; sr, oviducal seminal receptacle; sv, seminal vesicle; te, testes; ut, uterus; vd, vas deferens; vi, vitellarium.

\subsubsection{Paradeontacylix olivai $\mathrm{n}$. sp.}

\section{Description}

Host: Seriola lalandi Valenciennes, 1833.

Locality: San Jorge Bay $\left(23^{\circ} 35^{\prime} \mathrm{S}, 70^{\circ} 25^{\prime} \mathrm{W}\right)$, off Antofagasta, northern Chile. 
Location in host: Heart.

Prevalence: $20 \%$.

Representative sequences: GenBank accession numbers: partial 28S LSU rDNA MW599288; cox1 mDNA MW598469-70.

Etymology: The species is named in honor of Dr. Marcelo Oliva, who has studied marine parasites for over 40 years in Chile.

Specimens: Holotype and one paratype have been deposited in the MNHNCL, encoded as: PLAT-15019 and PLAT-15020, respectively.

Based on eight whole-mounted adult specimens. Body measurements are given in Table 3. Body smooth, elongated, dorsoventrally flattened, lancet-shaped (Figure 5A). Longer than wide by 11-18 $(13, \mathrm{n}=8)$ times. Marginal tegumental spines ventrolateral, 478-650 (563, $\mathrm{n}=6)$ rows on either side of body; same size throughout body, 3-14 per row, decreasing in number toward both extremities to about 3 at anterior end and 3-4 at posterior end. Posteriorly, 13-17 large tegumental spines, conspicuous, claw-like distally, arranged in 4 rows each comprising 3-5 spines (Figure 5C). Additionally, medium-sized posterior tegumental spines arranged on either side of large spines in 3 or 4 rows (Figure 5C).

Nerve commissure 137-209 $(166, \mathrm{n}=7)$ from anterior end. Mouth opening ventrosubterminally, 8-22 (16, $\mathrm{n}=7)$ from anterior end. Esophagus sinuous, $14-30 \%(25 \%, \mathrm{n}=7)$ of body length, gradually widening toward its end, surrounded by conspicuous gland cells positioned at 697-940 $(802, \mathrm{n}=6)$ from oesophagus anterior end. Short anterior and elongate posterior intestinal caeca forming X-shaped; anterior caeca and posterior caeca terminating blindly among testicular field, anterior to ovary (Figure 5A).

Testes arranged regularly in two rows between posterior extremities of caeca, round or ellipsoidal. Testicular field occupying 33-40\% $(36 \%, \mathrm{n}=8)$ of body length (Figure 5A). Vas deferens starting from posterior testes, passing dorsally to ovary, following a curved path to form seminal vesicle (Figure 5B). Seminal vesicle enclosed in cirrus sac (Figure 5B). Cirrus pouch cylindrical, thin-walled (Figure $5 \mathrm{~B})$. Male genital pore dorsal, 20-34 (27, $\mathrm{n}=7)$ from sinistral body margin, 429-542 (496, $n=7$ ) from posterior end of body (Figure 5B).

Ovary shield-shaped, distally elongated, posterior to testes, ventral to vas deferens, $778-1100(911, \mathrm{n}=8)$ from its posterior end to posterior end of body, corresponding to $21-23 \%(22 \%, n=8)$ of body length (Figure $5 \mathrm{~B})$. Oviduct originating at dextral posterior end part of ovary. Posterior part of oviduct expanding to form oviducal seminal receptacle (Figure 5B). Oviducal seminal receptacle narrowing progressively and joining common vitelline duct before forming oötype (Figure 5B). Oötype in mid-line, 330-443 (361, n =6) from posterior end of body, surrounded by Mehlis' gland (Figure 5B). Vitelline duct passing posteriorly, sinistral to oviduct. Uterus occupying zone from posterior end of ovary to oötype, sinistral to common vitelline duct, after ascending through several coils (filling space immediately posterior to ovary) and then descending to female genital pore (Figure 5B). Female genital pore dorsal, opening in midline, antero-dextral to male genital pore, 102-174 $(143, \mathrm{n}=5)$ from sinistral body margin, $167-204(190, \mathrm{n}=5)$ from male genital pore, 616-753 $(664, n=5)$ from posterior end of body. Eggs intrauterine, ellipsoidal (Figure 5B). Excretory vesicle and pore not observed. Vitellarium extending from level at or near nerve commissure to level of posterior end of ovary (Figure 5A).

\section{Remarks}

The distribution of testes in P. olivai n. sp. is regular, as they are distributed in two rows as in P. kampachi, P. buri, P. ibericus, and P. megalaspium. However, P. olivai n. sp. differs from P. buri as the latter does not have large posterior tegumental spines. P. olivai $\mathrm{n}$. sp. also has fewer testes as well as fewer and smaller large posterior tegumental spines than P. kampachi (41-45 vs. $50-71$ testes; ([3-5 spines] $\times 4$ rows) vs. ([2-7 spines] $\times$ [5-12 rows]) with length of 15-39 vs. 11-15, respectively). It also differs from P. ibericus, principally in the number and size of large posterior tegumental spines (([3-5 spines] $\times 4$ rows $)$ vs. ([2-3 spines $]$ $\times 5$ rows) with mean length of 24 vs. 13, respectively) and ovary shape (shield-shaped vs. kidney-shaped). Lastly, it differs from P. megalaspium by a combination of characters 
based on presence of large posterior tegumental spines (present vs. absent, respectively), maximum number of rows of transversal marginal tegumental spines (14 vs. 10, respectively), number of testes (41-45 vs. 70-86, respectively) and intestine shape (X-shaped vs. H-shaped, respectively).

P. olivai n. sp. differs from P. humboldti $\mathrm{n}$. sp. regarding the following traits: number of medium-sized posterior tegumental spines (([2-4 spines] $\times 3$ rows $)$ vs. ( 3 spines $\times 3$ rows), respectively), distribution of testes (regular, in two rows vs. irregular, respectively), number of testes (43 vs. 66 , respectively), ovary shape (shield-shaped vs. oval-shaped, respectively), intestine shape (X-shaped vs. H-shaped, respectively) and body length (3567-5214 vs. $1858-2353$, respectively).


Figure 5. Holotype of Paradeontacylix olivai n. sp. from heart of Seriola lalandi. (A) Ventral view of whole worm. (B) Ventral view of posterior part of body, showing one part of testicular field and post-ovarian region. (C) Posterior tegumental spines, showing large claw-like posterior tegumental spines. Abbreviations as in Figure 4. 


\section{Discussion}

The detection and correct identification of potential pathogenic parasites are an important as a first step to support emergent aquaculture [3,22]. The combination of morphologic and molecular characteristics is a strong and reliable method to identify species [32]. The conservative 28S LSU gene is an efficient marker for analyzing the phylogeny of digeneans at taxonomic levels, such as the genus and family [33,34], while the use of a mitochondrial marker as a DNA barcode has been useful for species discrimination [15,35]. Furthermore, using two or more independent loci (as in this study) provides advantages when estimating species-level relationships and testing hypotheses regarding species delimitation [36]. By analyzing new DNA sequences from P. humboldti $\mathrm{n}$. sp. and P. olivai $\mathrm{n}$. sp., our analysis complemented the previous analyses on the phylogenetic relationships between species of Paradeontacylix reported $[15,16]$. We found that $P$. godfreyi from $S$. lalandi in the Indian Pacific Ocean, south Australia, is located at the basal position within the Paradeontacylix spp. clade with strong nodal support. However, this result could be related to the genetic marker because previous authors used ITS-2 fragment, which is more variable than $28 \mathrm{~S}$ gene (domains C1-D2). Regardless of this difference in tree topology, previous authors $[15,16]$ demonstrated absence of influence of the host-phylogeography on the phylogenetic relationship of Paradeontacylix spp. in S. dumerili. More precisely, P. grandispinus (found in Japan) and P. balearicus (found in the Mediterranean) are genetically related as well as $P$. kampachi (found in Japan) and P. ibericus (found in the Mediterranean). Additionally, we found that the two new species, P. humboldti n. sp. and P. olivai n. sp. from S. lalandi in the southeastern Pacific, belong to the same (monophyletic) clade and represent a sister clade of $P$. balearicus and $P$. grandispinus. This suggests that they underwent a relatively recent divergence within the phylogeny of the genus Paradeontacylix. These results, however, must be confirmed using other more resolutive molecular markers.

The final host fish of Paradeontacylix spp., such as S. dumerili and S. lalandi, are known to be long-distance migratory fish species with genetically structured populations across their extensive geographical distributions [37-40]. Two populations of S. dumerili occur in the northeast Atlantic [39] and two other populations occur in the northwest Pacific [37]. This suggests that populations of this host species have undergone genetic divergence in the past as a consequence of historical processes [41,42] and that the ancestral parasite species had existed before the separation of the $S$. dumerili populations between Japan and the Mediterranean [15]. This would explain how a host fish species can come to harbor a pair of genetically related Paradeontacylix species (e.g., S. dumerili harbors P. grandispinus (in Japan) and P. balearicus (in the Mediterranean), and S. dumerili also harbors P. grandispinus (in Japan) and P. balearicus (in the Mediterranean)), which are reported to be restricted by the current geographical distribution of their host species populations. Similarly, there are at least four genetically distinct $S$. lalandi populations worldwide $[18,40]$ with a single population of $S$. lalandi distributed in the south Pacific [40]. However, the spatio-temporal genetic structure for $S$. lalandi from the southeastern Pacific coast (the same area as in the present study) [43] and two populations of S. lalandi (on the Australian and New Zealand coasts) have been reported [44]. This could explain the existence of the two new species of Paradeontacylix in S. lalandi in the southeastern Pacific (P. humboldti n. sp. and P. olivai n. sp.), which differ from the species P. godfreyi recorded in S. lalandi in the Indian Pacific [17]. Therefore, further studies are required to clarify whether one or more Paradeontacylix species parasitize S. lalandi on the Australian coast and to know whether this parasite presents high or low host specificity as suggested by Hutson and Whittinton [17].

All marine aporocotylids whose life cycles are known use terebellid polychaetes (Nicolea gracilibranchis, Longicarpus modestus, and Reterebella aloba; Terebella sp.; Neoamphitrite vigintipes) as intermediate hosts $[6,45,46]$. However, the intermediate hosts for Paradeontacylix spp. are unknown, but it has been suggested that, for aporocotylids, direct penetration by cercariae is the dominant infection route in fishes, i.e., the infection could be independent of the host diet [3]. This is critical information as it implies that the life cycle and infection potential of the parasite may be independent of the trophic web. Currently, in northern 
Chile the emerging aquaculture capture wild fish to improve the genetic variability of the brood fish, and already at least one dead fish has evidenced infection by Paradeontacylix spp. This means that if the parasite exists in the environment (in intermediate hosts and wild fishes), and if there is an open aquaculture system in the region, there is a high probability that the captive fish will acquire the parasite. In the practice, blood flukes of fish are difficult to detect as they infest the host vascular system [3,47]. Montero et al. [48] reported, for the first time, that although P. ibericus infections in farmed S. dumerili were undetectable based on macroscopic observation, there were encysted cercariae (schistosomula) in fixed histological sections of muscle, which could be useful for early diagnosis of this pathology. After experimentally evaluating the parasite development, they reported that small juvenile P. ibericus worms were still found in the muscles and lymphatic system $>100$ days after the transfer of the fish to tanks, and P. ibericus adults (with a recognizable reproductive system) were recovered 8 months after the transfer. There was a higher intensity of $P$. ibericus in the girdle muscles, head kidney, and sinus venosus (involving both juveniles and adult worms) while a low intensity (involving only adults) was detected in the gills. In our study, wild fish were infected mainly with $P$. olivai adults detected in the heart while farmed fish were infected with both species, although predominantly with P. humboldti, and numerous eggs were observed in the gills. Further studies focused to evaluate infection levels, proportion of each species, presence/absence of eggs in the gill, or heart and their variability in the sampling periods will be necessary to elucidate the early biological traits and life cycles of the two new blood fluke species infesting S. lalandi in the southeastern Pacific as it was done by Montero et al. [48].

As different parasites species can have different infection patterns and in turn respond differentially to control treatments, the identification of the two new species of Paradeontacylix described here is crucial to develop a diagnosis protocol of these potential pathogens in farmed fish, which should be accompanied by records on the occurrence of these parasites, monitoring of the fish condition, and mortality due to any of these parasites. This protocol will allow the implementation of preventive management and control of this potential disease in the emerging fish farming industry in Chile.

\section{Material and Methods}

\subsection{Sample Collection}

Twenty specimens of $S$. lalandi ranged between 46 and $84 \mathrm{~cm}$ fork length were acquired at a fish market in Antofagasta ( $\left.24^{\circ} \mathrm{S}\right)$, Chile, captured by an artisanal fishery in the nearshore area $\left(24^{\circ} \mathrm{S}-26^{\circ} \mathrm{S}\right)$ during the summer season (January-February) in 2018 and 2019. In these months, wild S. lalandi migrate to the Chilean coast when the water temperature $\left(17^{\circ} \mathrm{C}-21^{\circ} \mathrm{C}\right)$ increases [43]. Additionally, one specimen (about $4 \mathrm{~kg}$ ) of $S$. lalandi, captured in the summer of 2017 and maintained captive in the hatchery (with an open circulatory marine water intake and effluent system) of the Univ. Antofagasta was found dead and infected with blood flukes in August 2019. The fish was characterized as having an opened mouth and opercula, showing typical signs of suffocation. In the laboratory, the gills and heart of the fish were removed. Each heart was opened and washed in a Petri dish with freshwater, which was then filtered with a sieve. Each gill arch was dissected longitudinally and washed following the same protocol. The retained blood flukes were carefully separated according to the infection site (heart or gill) and fixed in $70 \%$ or $95 \%$ ethanol for taxonomic identification and molecular analysis, respectively. Parasitological indexes (mean intensity and prevalence) were calculated [49].

\subsection{Morphological Description and Morphometrical Analyses}

The flukes were stained with acetocarmine or Gomori's trichrome, dehydrated in ethanol (70-100\%), cleared with clove oil (Sigma-Aldrich, Taufkirchen, Germany), and mounted in Eukitt ${ }^{\circledR}$ mounting medium (O. Kindler GmbH, Freiburg, Germany). The flukes were photographed (M125 camera; Leica, Wetzlar, Germany) and measured using the ImageJ software [50]. Measurements were made in micrometers $(\mu \mathrm{m})$ and are given as 
the range, followed by the mean and the number of structures measured or counted in parentheses. Specimens were drawn using a compound microscope with a drawing tube. The type material was submitted to Museo Natural de Historia Natural (MNHNCL) in Santiago, Chile.

Morphometric analyses involved comparing the measurements of the specimens in this study with the measurements of P. godfreyi, P. sanguinicoloides, P. grandispinus, P. kampachi, $P$. balearicus, and P. ibericus obtained from original publications (Table 2). For this, we used the measurements (minimum and maximum) directly reported in the publications while other measurements were estimated from the drawings. P. buri and P. megalaspium were not considered because these species do not have large posterior tegumental spines. The source and number of specimens per host species and geographical area are given in Table 2.

To evaluate differences in morphometry among the fluke species, a principal component analysis (PCA) was performed using proportional body measurements as all relevant fluke measurements are correlated with body length [51]. For this analysis, the following 16 body measurements divided by total body length (BL) were used: maximum body width, number of marginal tegumental spine rows, posterior spine length, esophagus length, anterior caeca-intestine distance, posterior caeca-intestine distance, number of testes, testicular area length, male genital pore-posterior end distance, ovary length, ovary width, oviducal seminal receptacle length, oviducal seminal receptacle width, oötype length, oötype width, and female genital pore-posterior end distance. These analyses were performed using the Statistica 7.0 software (StatSoft Inc., Tulsa, OK, USA).

\subsection{Molecular Analysis}

\subsubsection{DNA Extraction and Amplification}

The DNA was isolated following a modified version of a protocol reported in [52]. This involved treatment with sodium dodecyl sulphate, digestion with proteinase $\mathrm{K}, \mathrm{NaCl}$ protein precipitation, and subsequent ethanol precipitation. The DNA was eluted in nucleasefree water and quantified using a BioSpec-nano spectrophotometer (Shimadzu, Japan).

For the molecular analyses, regions within the 28S ribosomal DNA large subunit (LSU rDNA) and the mitochondrial cytochrome $c$ oxidase 1 gene ( $c 0 x 1 \mathrm{mDNA}$ ) were amplified by polymerase chain reaction (PCR). LSU rDNA was amplified using the forward primer C1 (5'-ACCCGCTGAATTTAAGCAT-3') and the reverse primer D2 (5'TGGTCCGTGTTTCAAGAC-3') [53]; cox1 mtDNA was amplified using the forward primer JB3 (5'-TTTTTTGGGCATCCTGAGGTTTAT-3') and the reverse primer COX1 $\left(5^{\prime}\right.$-AATCATGATGCAAAAGGTA-3 ${ }^{\prime}$ [54]. Each PCR reaction was carried out in a final volume of $35 \mu \mathrm{L}$ comprising five standard units of GoTaq DNA polymerase (Promega), $7 \mu \mathrm{L}$ of $5 \times$ PCR buffer, $5.6 \mu \mathrm{L}$ of $\mathrm{MgCl}_{2}(25 \mathrm{mM}), 2.1 \mu \mathrm{L}$ of BSA $(10 \mathrm{mg} / \mathrm{mL}), 0.7 \mu \mathrm{L}$ of deoxynucleotide triphosphate (dNTP; $10 \mathrm{mM}$ ), $10 \mathrm{pM}$ of each primer, $3 \mu \mathrm{L}$ of template DNA, and sufficient nuclease-free $\mathrm{H}_{2} \mathrm{O}$ to make the total volume up to $35 \mu \mathrm{L}$. A Boeco Ecogermany M-240R Thermal Cycler (Boeckel, Hamburg, Germany) was used to carry out PCR for LSU rDNA and cox $1 \mathrm{mDNA}$ using the programs reported [53,54], respectively. The PCR products were sent to Macrogen (Seoul, Korea; http: / / www.macrogen.com, accessed on 15 December 2020) for purification and sequencing of both the DNA forward and reverse strands. The sequences were edited and contigs were assembled using ProSeq 2.9 beta [55]. All unique sequences obtained during this study were deposited into GenBank.

\subsubsection{Phylogenetic Reconstruction}

The sequences obtained in this study were aligned with sequences of Paradeontacylix spp. obtained from GenBank using Clustal X [56] (Table 1). Visual inspection was then performed using ProSeq v2.91 [55] in order to edit the length of the final dataset. The jModelTest v0.1.1 tool [57] was used to identify the best evolutionary model for each gene. Gene concatenation (LSU + cox1) was performed using Mesquite v2.75 [58]. Phylogenetic trees were constructed based on 28S LSU rDNA, cox1 mDNA, and the concatenated genes using Bayesian inference (BI) and maximum likelihood (ML) analyses. Five members of 
the Aporocotylidae family, Cardicola forsteri, C. opisthorchis, Psettarium nolani, P. sinense, and Plethorchis acanthus, were selected as outgroups based on their close phylogenetic relationships with the genus Paradeontacylix. Sequences of the outgroup taxa were obtained from GenBank (Table 1).

The BI analyses were conducted using MrBayes [59] with the following parameters: nst $=6$ and rates $=$ invgamma according to the evolutionary model determined by jModeltest v0.1.1 for each gene (GTR $+\mathrm{G}+\mathrm{I}$ for $28 \mathrm{~S}$ LSU rDNA and TIM2 + G + I for cox 1 mDNA, and replaced by GTR $+\mathrm{G}+\mathrm{I}$ for MrBayes software). Each analysis was performed for 5,000,000 generations, with one run of four chains, sampling every 100 generations. Support for nodes in the BI tree topology was based on posterior probability. The initial $25 \%$ was discarded as burn-in. The results were visualized using TRACER v1.7 [60]. The ML analyses were performed using W-IQ-TREE (http:/ /iqtree.cibiv.univie.ac.at/ [61] accessed on 15 March 2021), with 1000 bootstrap replicates for statistical support. The trees based on the concatenated genes were visualized and edited in FigTree v1.4.4 (http:/ / tree.bio.ed.ac.uk/software/figtree/, accessed on 15 March 2021).

Finally, the pairwise p-distances for LSU rDNA and $\operatorname{cox} 1$ mDNA sequences among multiple species of Paradeontacylix were analyzed using the MEGA v6 software [62].

\section{Conclusions}

P. humboldti n. sp. and P. olivai n. sp. described in the present study constitute two new species of blood flukes that infest Seriola lalandi. The identity of each of the two new species is supported by morphological, morphometric, and molecular data.

Supplementary Materials: The following are available online at https:/ / www.mdpi.com/article/10 .3390 / pathogens10070849/s1. Figure S1: Eggs of Paradeontacylix olivai n. sp infesting gills of farmed Seriola lalandi. Table S1: Sequences 28 S and Cox-1, obtained by the DNA Sanger sequencing, for Paradeontacylix humboldti n. sp. and P. olivai n. sp. infecting Seriola lalandi (Chile).

Author Contributions: Conceptualization, F.A.S. and M.T.G.; formal analysis, F.A.S., L.A.Ñ. and M.T.G.; funding acquisition, M.T.G.; investigation, F.A.S. and L.A.Ñ.; supervision, M.T.G.; writingoriginal draft, F.A.S. and M.T.G. All authors have read and agreed to the published version of the manuscript.

Funding: This research was funded by Project Semillero of Vicerrectoría Investigación y Postgrado (VRIIP), Universidad de Antofagasta, Chile, grant number 5303.

Institutional Review Board Statement: Not applicable.

Informed Consent Statement: Not applicable.

Data Availability Statement: The new data are available at https://www.ncbi.nlm.nih.gov/genbank/, accessed on 15 March 2021.

Acknowledgments: We thank the technician Marcelo Abarca of the University of Antofagasta for his collaboration to obtain dead specimens of experimental yellowtail kingfish. This research was supported by project 5303 VRIIP, Universidad de Antofagasta (Chile) granted to M.T.G.

Conflicts of Interest: The authors declare no conflict of interest.

Ethics Statements: Not applied due to fish used for this study were previously captured by fishermen and the farmed fish was found dead in the tank.

\section{References}

1. Rohde, K. Marine Parasitology; Csiro Publishing: Melbourne, Australia; CAB International: Melbourne, Australia, $2005 ;$ p. 592.

2. Holzer, A.S.; Montero, F.E.; Repullés, A.; Nolan, M.J.; Sitja-Bobadilla, A.; Alvarez-Pellitero, P.; Zarza, C.; Raga, J.A. Cardicola aurata sp. n. (Digenea: Sanguinicolidae) from Mediterranean Sparus aurata L. (Teleostei: Sparidae) and its unexpected phylogenetic relationship with Paradeontacylix McIntosh, 1934. Parasitol. Int. 2008, 57, 472-482. [CrossRef]

3. Power, C.; Nowak, B.F.; Cribb, T.H.; Bott, N.J. Bloody flukes: A review of aporocotylids as parasites of cultured marine fishes. Int. J. Parasitol. 2020, 50, 743-753. [CrossRef] [PubMed]

4. Ogawa, K.; Egusa, S. Two new species of Paradeontacylix Mcintosh, 1934 (trematoda: Sanguinicolidae) from the vascular system of a cultured marine fish, Seriola purpurascens. Fish Pathol. 1986, 21, 15-19. [CrossRef] 
5. Crespo, S.; Grau, A.; Padros, F. Sanguinocoliasis in the cultured amberjack Seriola dumerili Risso, from the spanish Mediterranean area. Bull. Eur. Ass. Fish Pathol. 1992, 12, 157.

6. Shirakashi, S.; Tani, K.; Ishimaru, K.; Shin, S.P.; Honryo, T.; Uchida, H.; Ogawa, K. Discovery of intermediate hosts for two species of blood flukes Cardicola orientalis and Cardicola forsteri (Trematoda: Aporocotylidae) infecting Pacific bluefin tuna in Japan. Parasitol. Int. 2016, 65, 128-136. [CrossRef]

7. Sugihara, Y.; Yamada, T.; Ichimaru, T.; Matsukura, K.; Kanai, K. Detection of bluefin tuna blood flukes (Cardicola spp.) from wild juvenile Pacific bluefin tuna Thunnus orientalis caught for aquaculture. Aquaculture 2016, 452, 9-11. [CrossRef]

8. Ogawa, K.; Hattori, K.; Hatai, K.; Kubota, S. Histopathology of cultured marine fish, Seriola Purpurascens (Carangidae) infected with Paradeontacylix spp. (Trematoda: Sanguinicolidae) in its vascular system. Fish Pathol. 1989, 24, 75-81. [CrossRef]

9. Kirk, R.S.; Lewis, J.W. Histopathology of Sanguinicola inermis infection in carp, Cyprinus carpio. J. Helminthol. 1998, 72, 33-38. [CrossRef] [PubMed]

10. Padrós, F.; Zarza, C.; Crespo, S. Histopathology of cultured sea bream Sparus aurata infected with sanguinicolid trematodes. Dis. Aquat. Organ. 2001, 44, 47-52. [CrossRef] [PubMed]

11. Paperna, I.; Dzikowski, R. Chapter 10 Digenea (Phylum Platyhelminthes). In Fish Diseases and Disorders, Volume 1: Protozoan and Metazoan Infections; Woo, P.T.K., Ed.; CABI: Wallingford, UK; University of Guelph: Guelph, ON, Canada, 2006 ; p. 800.

12. Ogawa, K.; Fukudome, M. Mass mortality caused by blood fluke (Paradeontacylix) among Amberjack (Seriola dumeili) imported to Japan. Fish Pathol. 1994, 29, 265-269. [CrossRef]

13. Crespo, S.; Grau, A.; Padros, F. The intensive culture of 0-group amberjack in the western Mediterranean is compromised by disease problems. Aquac. Int. J. Eur. Aquac. Soc. 1994, 2, 262-265. [CrossRef]

14. McIntosh, A. A new blood trematode, Paradeontacylix sanguinicoloides n.g., n.sp., from Seriola lalandi with a key to the species of the family aporocotylidae. Parasitology 1934, 26, 463-467. [CrossRef]

15. Repullés-Albelda, A.; Montero, F.E.; Holzer, A.S.; Ogawa, K.; Hutson, K.S.; Raga, J.A. Speciation of the Paradeontacylix spp. (Sanguinicolidae) of Seriola dumerili. Two new species of the genus Paradeontacylix from the Mediterranean. Parasitol. Int. 2008, 57, 405-414. [CrossRef] [PubMed]

16. Ogawa, K.; Akiyama, K.; Grabner, D. Paradeontacylix buri n. sp. (Trematoda: Aporocotylidae) from Seriola quinqueradiata cultured in Japan with a description of unidentified Paradeontacylix sp. from S. lalandi. Fish Pathol. 2015, 50, 183-191. [CrossRef]

17. Hutson, K.S.; Whittington, I.D. Paradeontacylix godfreyi n. sp. (Digenea: Sanguinicolidae) from the heart of wild Seriola lalandi (Perciformes: Carangidae) in southern Australia. Zootaxa 2006, 1151, 55. [CrossRef]

18. Martinez-Takeshita, N.; Purcell, C.M.; Chabot, C.L.; Craig, M.T.; Paterson, C.N.; Hyde, J.R.; Allen, L.G. A tale of three tails: Cryptic speciation in a globally distributed marine fish of the genus Seriola. Copeia 2015, 103, 357-368. [CrossRef]

19. Layman, E.M. Parasitic worms from the fishes of Peter The Great Bay. Bull. Pac. Sci. Fish. Res. Stn. 1930, 3, 1-120.

20. Lakshmi, T.T.; Madhavi, R. Paradeontacylix megalaspium n. sp. (Digenea: Sanguinicolidae) from the carangid fish, Megalaspis cordyla of Bay of Bengal. Zootaxa 2007, 1512, 65-68. [CrossRef]

21. Hutson, K.S.; Ernst, I.; Whittington, I.D. Risk assessment for metazoan parasites of yellowtail kingfish Seriola lalandi (Perciformes: Carangidae) in South Australian sea-cage aquaculture. Aquaculture 2007, 271, 85-99. [CrossRef]

22. Bullard, S.A.; Overstreet, R.M. Potential pathological effects of blood flukes (Digenea: Sanguinicolidae) on Pen-reared Marine Fishes. Fac. Publ. Harold W. Manter Lab. Parasitol. 2002, 414, 10-25.

23. Ogawa, K.; Yokoyama, H. Parasitic diseases of cultured marine fish in Japan. Fish Pathol. 1998, 33, 303-309. [CrossRef]

24. Ogawa, K. Diseases of cultured marine fishes caused by Platyhelminthes (Monogenea, Digenea, Cestoda). Parasitology 2015, 142, 178-195. [CrossRef] [PubMed]

25. Orellana, J.; Waller, U.; Wecker, B. Culture of yellowtail kingfish (Seriola lalandi) in a marine recirculating aquaculture system (RAS) with artificial seawater. Aquac. Eng. 2014, 58, 20-28. [CrossRef]

26. Fernández, G.; Cichero, D.; Patel, A.; Martínez, V. Estructura genética de poblaciones chilenas de Seriola lalandi para la diversificación de la acuicultura nacional en el norte de Chile. Lat. Am. J. Aquat. Res. 2015, 43, 374-379. [CrossRef]

27. Bravo, S.; Hurtado, C.F.; Silva, M.T. Coinfection of Caligus lalandei and Benedenia seriolae on the yellowtail kingfish Seriola lalandi farmed in a net cage in northern Chile. Lat. Am. J. Aquat. Res. 2017, 45, 852-857. [CrossRef]

28. Sepúlveda, F.A.; González, M.T. Patterns of genetic variation and life history traits of Zeuxapta seriolae infesting Seriola lalandi across the coastal and oceanic areas in the southeastern Pacific Ocean: Potential implications for aquaculture. Parasit. Vectors 2015, 8, 282. [CrossRef]

29. Sepúlveda, F.A.; González, M.T. Molecular and morphological analyses reveal that the pathogen Benedenia seriolae (Monogenea: Capsalidae) is a complex species: Implications for yellowtail Seriola spp. aquaculture. Aquaculture 2014, 418-419, 94-100. [CrossRef]

30. Baeza, J.A.; Sepúlveda, F.A.; González, M.T. The complete mitochondrial genome and description of a new cryptic species of Benedenia Diesing, 1858 (Monogenea: Capsalidae), a major pathogen infecting the yellowtail kingfish Seriola lalandi Valenciennes in the South-East Pacific. Parasit. Vectors 2019, 12, 490. [CrossRef]

31. Sepúlveda, F.A.; González, M.T. DNA barcoding evidence for the first recorded transmission of Neobenedenia sp. from wild fish species to Seriola lalandi cultured in an open recirculating system on the Coast of Northern Chile. Aquaculture 2019, 501, 239-246. [CrossRef] 
32. Pečnikar, Ž.F.; Buzan, E.V. 20 years since the introduction of DNA barcoding: From theory to application. J. Appl. Genet. 2014, 55, 43-52. [CrossRef]

33. Nolan, M.J.; Cribb, T.H. Two new blood flukes (Digenea: Sanguinicolidae) from Epinephelinae (Perciformes: Serranidae) of the Pacific Ocean. Parasitol. Int. 2004, 53, 327-335. [CrossRef] [PubMed]

34. Pérez-Ponce de León, G.; Hernández-Mena, D.I. Testing the higher-level phylogenetic classification of Digenea (Platyhelminthes, Trematoda) based on nuclear rDNA sequences before entering the age of the 'next-generation' tree of life. J. Helminthol. 2019, 93, 260-276. [CrossRef] [PubMed]

35. Morgan, J.A.T.; Blair, D. Relative merits of nuclear ribosomal internal transcribed spacers and mitochondrial CO1 and ND1 genes for distinguishing among Echinostoma species (Trematoda). Parasitology 1998, 116, 289-297. [CrossRef] [PubMed]

36. Callejón, R.; Cutillas, C.; Nadler, S.A. Nuclear and mitochondrial genes for inferring Trichuris phylogeny. Parasitol. Res. 2015, 114, 4591-4599. [CrossRef]

37. Nugroho, E.; Taniguchi, N.; Kato, K.; Miyashita, S. Genetic difference among seed populations of greater amberjack used in aquaculture farm of Japan. Suisanzoshoku 2000, 48, 665-674. [CrossRef]

38. Nugroho, E.; Ferrell, D.J.; Smith, P.; Taniguchi, N. Genetic divergence of kingfish from Japan, Australia and New Zealand inferred by microsatellite DNA and mitochondrial DNA control region markers. Fish. Sci. 2001, 67, 843-850. [CrossRef]

39. Šegvić-Bubić, T.; Marrone, F.; Grubišić, L.; Izquierdo-Gomez, D.; Katavić, I.; Arculeo, M.; Lo Brutto, S. Two seas, two lineages: How genetic diversity is structured in Atlantic and Mediterranean greater amberjack Seriola dumerili Risso, 1810 (Perciformes, Carangidae). Fish. Res. 2016, 179, 271-279. [CrossRef]

40. Premachandra, H.K.A.; Lafarga-De la Cruz, F.; Takeuchi, Y.; Miller, A.; Fielder, S.; O'Connor, W.; Frère, C.H.; Nguyen, N.H.; Bar, I.; Knibb, W. Genomic DNA variation confirmed Seriola lalandi comprises three different populations in the Pacific, but with recent divergence. Sci. Rep. 2017, 7, 9386. [CrossRef]

41. Slatkin, M. Gene flow and the geographic structure of natural populations. Science 1987, 236, 787-792. [CrossRef] [PubMed]

42. Nadler, S.A. Microevolution and the genetic structure of parasite populations. J. Parasitol. 1995, 81, 395. [CrossRef]

43. Sepúlveda, F.A.; González, M.T. Spatio-temporal patterns of genetic variations in populations of yellowtail kingfish Seriola lalandi from the south-eastern Pacific Ocean and potential implications for its fishery management. J. Fish Biol. 2017, 90, 249-264. [CrossRef] [PubMed]

44. Miller, P.A.; Fitch, A.J.; Gardner, M.; Hutson, K.S.; Mair, G. Genetic population structure of Yellowtail Kingfish (Seriola lalandi) in temperate Australasian waters inferred from microsatellite markers and mitochondrial DNA. Aquaculture 2011, 319, 328-336. [CrossRef]

45. Cribb, T.H.; Adlard, R.D.; Hayward, C.J.; Bott, N.J.; Ellis, D.; Evans, D.; Nowak, B.F. The life cycle of Cardicola forsteri (Trematoda: Aporocotylidae), a pathogen of ranched southern bluefin tuna, Thunnus maccoyi. Int. J. Parasitol. 2011, 41, 861-870. [CrossRef] [PubMed]

46. Shirakashi, S.; Ogawa, K. Blood fluke infections in marine cultured fish. Fish Pathol. 2016, 51, 92-98. [CrossRef]

47. Ogawa, K. Marine parasitology with special reference to Japanese fisheries and mariculture. Vet. Parasitol. 1996, 64, 95-105. [CrossRef]

48. Montero, F.E.; Kostadinova, A.; Raga, J.A. Development and habitat selection of a new sanguinicolid parasite of cultured greater amberjack, Seriola dumerili, in the Mediterranean. Aquaculture 2009, 288, 132-139. [CrossRef]

49. Bush, A.O.; Lafferty, K.D.; Lotz, J.M.; Shostak, A.W. Parasitology meets ecology on its own terms: Margolis et al. revisited. J. Parasitol. 1997, 83, 575. [CrossRef] [PubMed]

50. Abràmoff, M.D.; Magalhães, P.J.; Ram, S.J. Image processing with imageJ. Biophotonics Int. 2004, 11, 36-41. [CrossRef]

51. Quinn, G.P.; Keough, M.J. Chapter 17: Principal components and correspondence analysis. In Experimental Design and Data Analysis for Biologists; Quinn, G.P., Keough, M.J., Eds.; Cambridge University Press: Cambridge, UK, 2002 ; pp. 444-472.

52. Miller, S.A.; Dykes, D.D.; Polesky, H.F. A simple salting out procedure for extracting DNA from human nucleated cells. Nucleic Acids Res. 1988, 16, 1215. [CrossRef]

53. Chisholm, L.A.; Whittington, I.D.; Morgan, J.A.T.; Adlard, R.D. The Calicotyle conundrum: Do molecules reveal more than morphology? Syst. Parasitol. 2001, 49, 81-87. [CrossRef]

54. Leung, T.L.; Donald, K.M.; Keeney, D.B.; Koehler, A.V.; Peoples, R.C.; Poulin, R. Trematode parasites of Otago Harbour (New Zealand) soft-sediment intertidal ecosystems: Life cycles, ecological roles and DNA barcodes. N. Z. J. Mar. Freshw. Res. 2009, 43, 857-865. [CrossRef]

55. Filatov, D.A. PROSEQ: A software for preparation and evolutionary analysis of DNA sequence data sets. Mol. Ecol. Notes 2002, 2, 621-624. [CrossRef]

56. Larkin, M.A.; Blackshields, G.; Brown, N.P.; Chenna, R.; McGettigan, P.A.; McWilliam, H.; Valentin, F.; Wallace, I.M.; Wilm, A.; Lopez, R.; et al. Clustal W and clustal X version 2.0. Bioinformatics 2007, 23, 2947-2948. [CrossRef] [PubMed]

57. Posada, D. jModelTest: Phylogenetic model averaging. Mol. Biol. Evol. 2008, 25, 1253-1256. [CrossRef] [PubMed]

58. Massidon, W.P.; Maddison, D.R. Mesquite: A modular System for Evolutionary Analysis. Version 2.75. Available online: https:/ / ci.nii.ac.jp/naid/20001328793 (accessed on 15 January 2021).

59. Huelsenbeck, J.P.; Ronquist, F. MrBAYES: Bayesian inference for phylogeny trees. Bioinformatics 2001, 17, 754-755. [CrossRef] [PubMed] 
60. Rambaut, A.; Drummond, A.J.; Xie, D.; Baele, G.; Suchard, M.A. Posterior summarization in bayesian phylogenetics using tracer 1.7. Syst. Biol. 2018, 67, 901-904. [CrossRef]

61. Trifinopoulos, J.; Nguyen, L.T.; von Haeseler, A.; Minh, B.Q. W-IQ-TREE: A fast online phylogenetic tool for maximum likelihood analysis. Nucleic Acids Res. 2016, 44, W232-W235. [CrossRef]

62. Tamura, K.; Stecher, G.; Peterson, D.; Filipski, A.; Kumar, S. MEGA6: Molecular evolutionary genetics analysis version 6.0. Mol. Biol. Evol. 2013, 30, 2725-2729. [CrossRef] 